\title{
Andrew Pettinger, The Republic in Danger: Drusus Libo and the Succession of Tiberius. Oxford: Oxford University Press, 2012. Pp. ix, 265. ISBN 978-0-19-960174-5. \$99.00.
}

Karey Rodgirs

In this revised version of his $\mathrm{PhD}$ thesis Andrew Pettinger offers a new analysis of the early Principate, one which challenges conventional beliefs about the succession schemes of Augustus and the ascension of Tiberius. The study begins with a desire to understand the trial of $\mathrm{M}$. Scribonius Drusus Libo in AD 16 and leads into an investigation of the murder of Agrippa Postumus and early opposition to Tiberius. Seeking to challenge the view held by modern scholarship that the transition from Augustus to Tiberius was relatively seamless, The Republic in Danger argues that there was in fact a large faction of wealthy Romans who opposed Tiberius and had been trying to prevent him from coming to power for years. Pettinger's history attempts to take many seemingly unrelated anecdotes from the years $6 \mathrm{BC}-\mathrm{AD} 16$ and connect them to tell a holistic and coherent story about the succession of Tiberius.

Pettinger divides his argument into two parts. To begin, he focuses on the issues surrounding M. Scribonius Drusus Libo (Pettinger 2012, 6-37). Tacitus provides the most detailed account of Drusus Libo's trial, but Pettinger notes that Tacitus' explanation for it-that Drusus Libo was a harmless young man destroyed by delators for the sake of profit-is at odds with the details of the case (9). Pettinger argues that the accusations against Drusus Libo were taken too seriously for the man to have been a harmless victim of entrapment, and that the only explanation for the senate to treat him with as much urgency and seriousness as they did would be if they believed that he had the means to incite revolution. Pettinger believes it is significant that in that same year a slave disguised as Agrippa Postumus was gathering support for a civil war. Therefore, he argues, Drusus Libo must have been involved or strongly suspected to be involved with the supporters of Pseudo-Agrippa. By citing legal precedent and Roman religious practice, Pettinger is able to make a convincing argument that Drusus Libo represented a real danger in the minds of those who prosecuted him and that the conception of Drusus Libo as a stupidly ambitious but ultimately harmless young man must have been a later development (27). However, dismissing Tacitus' interpretation of the case does not prove that Drusus Libo was part of the Pseudo-Agrippa conspiracy. To connect Drusus Libo with Psuedo-Agrippa, Pettinger acknowledges that a better understanding of Agrippa Postumus and his supporters is required (37).

The rest of the book embarks on a detailed analysis of Agrippa Postumus and his political significance during the years $6 \mathrm{BC}-16 \mathrm{AD}$. Pettinger's position is not that Agrippa Postumus was personally opposed to Tiberius, but rather an anti-Tiberian group was intent on using the boy to incite a popular revolution (121). Pettinger argues that Augustus adopted Agrippa in AD 4 because the boy represented a potential problem: he was rich, his parents were dead or in exile, and his brother Gaius Caesar, once the heir apparent, had just recently died. Suddenly, people who had counted on Gaius' friendship for their political advancement were facing an uncertain future. They could not cultivate 'Tiberius' friendship because of past hostilities, but Agrippa was an attractive alternative (53). Pettinger argues that Agrippa's adoption and subsequent exile was an effort by Augustus to keep him away from people who would try to help him gain power (73). Pettinger makes his case by demonstrating that periods of civil unrest in Rome correlate with the dates of Agrippa's adoption, relegation, and imprisonment and by noting that efforts to rescue him occurred 
when Augustus was sick or close to death (105). Based on these correlations and the treasonous activities of Agrippa's stepbrother L. Aemilius Paullus, Pettinger identifies the relatives of Scribonia and her daughters as the main supporters of Agrippa (100, 184, 228-9). He concludes that M. Scribonius Drusus Libo, Scribonia's nephew, was part of the Pseudo-Agrippa conspiracy as part of a last ditch attempt to use Agrippa's name to resist the supremacy of Tiberius.

A noteworthy section is the prosopography of Drusus Libo included in Appendix 1 (219-32). Drusus Libo's Scribonian heritage is a key element in Pettinger's argument and this thorough study of his social and political background is a valuable addition to the work. The prosopography highlights the importance of Drusus Libo's grandfather L. Scribonius Libo during the civil war between Caesar and Pompey in the late Republic, as well as the importance of this man's descendants to the aristocracy of Rome in general. For a student of Roman history the prosopography is a worthwhile read, because it highlights the importance of nomenclature to Roman conceptions of social status in addition to providing essential context to Pettinger's understanding of the Principate.

Pettinger's methodology allows him to connect several seemingly unconnected events in ways that have not been considered before. By trying to look beyond what the sources say explicitly and consider different events and sources in context with each other, Pettinger is able to theorise what events 'mean' when the reasons given by the ancient sources seem improbable. He considers his conclusions about Libo's trial against legal and historical precedents to establish explanations that are consistent with Roman patterns of behaviour. He also overtly situates his work within the context of modern scholarship. Pettinger draws on the expertise of many different scholars, but more memorable to the reader is just how many of Pettinger's theories diverge from current or commonly accepted views. Pettinger actively engages with the theories and contributions of his predecessors, to the extent that the footnotes take up a significant portion of each page. By describing and refuting views that stand in opposition to his own, Pettinger invites his readers to enter the debate and question his findings.

Another striking element of Pettinger's study is his treatment and presentation of the sources. Pettinger draws on a variety of ancient sources to support his arguments and provides a direct excerpt whenever possible, often providing three or more different excerpts in reference to the same topic. The passages are always presented in their original Latin or Greek, followed by Pettinger's own translations. This method creates the feeling that one is reading a sourcebook and encourages a sense of authenticity in Pettinger's writing. Because so much of Pettinger's arguments arise out of his own specific interpretations of the sources, combing original language quotations and translations allow both scholarly and lay readers to follow and evaluate the logic of his conclusions for themselves.

The Republic in Danger is full of new or relatively unknown ideas about the early Principate that may warrant further study. One of Pettinger's better ideas is the argument that the order to execute Agrippa came not from Augustus or Tiberius but rather from Augustus' most trusted advisor, Sallustius Crispus (177-9). The nature of Agrippa's execution is a much-debated point both in ancient and modern thought, and Pettinger's solution is that it cannot have been Tiberius, Augustus, or Livia because if it were, the other two would have known and been complicit. He says that 'Tiberius' apparently genuine surprise at Agrippa's death negates the possibility that it was one of them. Relying on a detail in Tacitus that differs from other ancient versions of the story, Pettinger makes an argument that Tacitus had access to a source that no one else did and was able to learn something no one else knew: Sallustius Crispus was the real culprit. This is an interesting solution to 
an old problem, and it raises questions that could be investigated further. However, some of Pettinger's ideas appear to be formed on very little evidence as well.

For example, in either AD 3 or 4, the Elder Julia's exile was relaxed and she was moved to the mainland, apparently in response to public protests on her behalf (47-9). Pettinger concludes that L. Aemilius Paullus was responsible for stirring up public support for the Elder Julia because he was married to the Younger Julia, had held the consulship with Gaius Caesar in AD 1, and would later be exiled for treason. According to Pettinger, supporting the Elder Julia would correlate to support for her son Agrippa Postumus, and adds to his argument that Paullus was part of a shadowy Scribonian resistance faction. The problem is that Pettinger offers no actual evidence to support Paullus' involvement in the softening of Julia's living conditions. Furthermore, because the timing for Julia's relocation as given in Suetonius can be interpreted as AD 3 or AD 4, Pettinger chooses AD 4 simply because it is more convenient for his theory. However, if it were AD 3, his theory would fall apart because Gaius Caesar was still alive and Agrippa was still insignificant. Connecting Paullus, Julia, and Agrippa in AD 4 is not ultimately vital to Pettinger's overall theory, but it does indicate a strong and potentially problematic desire to make things 'fit.'

Despite occasionally stretching his speculations too far, overall Pettinger's study is an enjoyable read and an ambitious retelling of the transition period between Augustus and Tiberius. Whether or not Drusus Libo was actually involved with the Pseudo-Agrippa conspiracy is not something that can ever be known or directly proven and I do not think that Pettinger's research is able to make a completely convincing connection between the two because so much of his theory is based on speculation rather than evidence. That being said, the strength of Pettinger's approach comes from his consideration of the larger social fabric of the Roman aristocracy, allowing him to formulate new ways of understanding old problems. The Republic in Danger is a worthwhile and enjoyable read because it offers a fresh take on the ways in which the Principate was accepted and resisted by the people it tried to govern. 